\title{
Criatividade no ensino superior: uma perspectiva internacional
}

\author{
Creativity in higher education: an international perspective
}

\author{
Creatividad en la enseñanza superior: una perspectiva internacional
}

Wechsler, S. M., \& Nakano, T. C. (2011). Criatividade no Ensino Superior: uma perspectiva internacional. São Paulo: Vetor Editora

\begin{abstract}
O estudo da criatividade vem se expandindo e sendo valorizado no âmbito científico por diferentes profissionais e em diferentes contextos. Assim, observa-se um grande interesse a respeito da temática no contexto educacional. Diante dessa constatação, a obra foi desenvolvida, tendo como objetivo comparar visões teóricas e empíricas de diferentes pesquisadores (nacionais e internacionais) voltadas à investigação da criatividade no Ensino Superior.

O livro Criatividade no Ensino Superior: uma perspectiva internacional, de autoria de Solange Muglia Wechsler e Tatiana de Cássia Nakano, é dividido em duas partes. A primeira, composta de quatro capítulos, aborda as perspectivas teóricas acerca da temática e a segunda, com cinco capítulos, focaliza as perspectivas práticas. Faz-se relevante mencionar que tal organização estimula o leitor a compreender inicialmente o fenômeno a nível teórico, para depois compreendê-lo em diferentes aplicações práticas.

$\mathrm{Na}$ parte teórica, o primeiro capítulo, denominado "Competências criativas no Ensino Superior", tem como autores Ana Paula David, Tatiana de Cássia Nakano, Maria de Fátima Morais e Ricardo Primi, os quais trazem um breve histórico da educação, acompanhado da conceituação para o fenômeno da criatividade e de como esta vem sendo aplicada nos diferentes contextos educacionais, além de abordarem pesquisas relevantes sobre esse construto no Ensino Superior. O capítulo dois, de Adelinda Candeias, Nicole Rebelo, João Silva e Patrícia Mendes, intitulado "Excelência vs. competência: um desafio para a educação e o desenvolvimento profissional", aborda a exigência atual dos contextos sociais por sujeitos criativos e competentes. Interessante citar
\end{abstract}

que o capítulo faz menção à problemática enfrentada pela educação frente a essa exigência, uma vez que se, por um lado, esse contexto almeja indivíduos criativos, formadores de ideias, capazes de observar lacunas e supri-las em seu ambiente de trabalho, por outro, o que se tem visto é que a educação formal estimula a absorção de regras, a reprodução de conhecimentos, ao invés da inovação, fortalecendo os meios tradicionais de ensino e barrando a criatividade. A partir dessa perspectiva, os autores discutem o que significa ser excelente em uma visão educacional e profissional, bem como as competências de excelência que podem ser promovidas nos contextos familiar, educacional e organizacional.

O capítulo três, intitulado "Compreender a criatividade nas organizações: contributos da Psicologia do Trabalho", de autoria de Maria Isabel Torres-Oliveira, expõe, através de uma perspectiva histórica, a compreensão da criatividade, destacando o construto no campo organizacional, visto que sua compreensão e importância têm sido marcadas, muitas vezes, como pertencente somente ao contexto educacional. A necessidade de exploração de estudos na área de criatividade é também compartilhada por Zula Giglio no capítulo quatro, "Educação não formal: onde cabe a criatividade?". A autora relata que muitos são os estudos que abordam a temática no contexto de educação formal, sendo essa característica pouco priorizada na educação não formal. A partir dessa perspectiva, o capítulo traz conceituações e um panorama histórico brasileiro do contexto, ressaltando a necessidade de mais estudos na área.

Iniciando a parte de perspectivas práticas, Maria de Fátima Morais e Ivete Azevedo, no capítulo cinco, "Escu- 
tando os professores portugueses acerca da criatividade: alguns resultados e reflexões sobre a sua formação", fazem menção a um estudo empírico com professores no contexto educacional, bem como transcrevem relatos como sugestões para a atuação do papel do professor, visto que esse é o agente de mudança da sala de aula. No capítulo posterior, denominado "Criatividade na Educação Superior na perspectiva de estudantes e professores", de Eunice M. L. Soriano de Alencar, a autora faz um breve histórico de diversos estudos brasileiros com objetivos diferentes que estão relacionados à promoção e inibição da criatividade na visão de estudantes e professores do Ensino Superior, a fim de promover a criatividade no contexto universitário.

O capítulo sete, denominado "Criatividade na universidade: potencialidade e possibilidades de transformação" e escrito por Suzana de Jesus Fadel e Solange Muglia Wechsler, apresenta os resultados de um estudo empírico com o objetivo de identificar a percepção de professores universitários brasileiros quanto ao desenvolvimento da criatividade. Interessante observar a importância que os autores salientam acerca da necessidade de estimulação da criatividade dos professores, a utilização de diferentes metodologias de ensino e a quebra de barreiras tradicionais. Esse capítulo tem como diferencial a demonstração da possibilidade do incentivo ao fenômeno também em níveis mais avançados de ensino.

O capítulo "Avaliação dos estilos de pensar e criar em universitários", das autoras Tatiana de Cássia Nakano e Luciana Gurgel Guida Siqueira, traz as conceituações dos estilos cognitivos de pensar e criar, apresentando um instrumento para sua avaliação, assim como pesquisas brasileiras que fizeram uso desse instrumento tendo como foco sua investigação no Ensino Superior. Do mesmo modo, Gildene de Ouro Lopes Silva e Solange Muglia Wechsler finalizam a se- gunda parte da obra com o capítulo nove, intitulado "Desafios do professor universitário: o encontro da criatividade com os estilos de aprender", no qual enfatizam os estilos de aprender, ressaltando a importância da sua identificação no processo de aprendizagem e os benefícios advindos desse processo.

De modo geral, considerando a importância da temática, a obra traz importantes contribuições para área da Psicologia, assim como para outras áreas do conhecimento que estudam e se interessam pela temática da criatividade ou pela educação superior. O livro expõe questões teóricas e práticas a respeito da criatividade, de maneira que sua organização acaba se constituindo em um diferencial quando comparado a outras obras existentes acerca da temática, já que apresenta não só a visão de autores brasileiros, mas também o olhar de autores internacionais. Além disso, pode-se considerar que o livro possui uma linguagem clara e compreensível, acessível a profissionais, pesquisadores, estudantes da área e também leitores que se interessem pelo tema e que visam encontrar referências teóricas e conhecimentos práticos com a finalidade de potencializar o seu próprio desenvolvimento

Vale ressaltar ainda que o livro traz especificações da criatividade em um contexto no qual existem poucas pesquisas científicas focadas, o contexto do Ensino Superior. Acredita-se que esse enfoque possa incentivar e impulsionar a produção de futuras pesquisas na área, visto que a predominância de trabalhos publicados refere-se ao contexto de Ensino Básico. Por fim, pode-se dizer que a obra atende ao objetivo de transmitir conhecimento e ser uma referência para profissionais, principalmente da educação, que se importam em exercer com qualidade o seu papel de educador, buscando formar universitários que contribuirão para o futuro da sociedade.

\section{Sobre as autoras}

Carolina Rosa Campos (carolene_crc@hotmail.com)

PUC-Campinas, bolsista de Mestrado em Psicologia CNPq.

Endereço para correspondência: R. Ferreira Penteado, 960, apto 2B.

CEP 13010-041. Centro. Campinas - São Paulo.

Talita Fernanda da Silva (talita_fs@ig.com.br)

PUC-Campinas, bolsista de Mestrado em Psicologia CNPq.

Endereço para correspondência: R. Major Solon, 634, apto 101.

CEP 13015-101. Cambuí. Campinas - São Paulo. 